\title{
Inhibitory Effect of Roselle Aqueous Extracts- HPMC 6000 Gel on the Growth of Staphylococcus Aureus ATCC 25923
}

\author{
Hibiscus Sabdariffa L Sulu Ekstrelerini İçeren HPMC 6000 Jel \\ Formülasyonunun Staphylococcus Aureus ATCC 25923 Büyümesi Üzerine \\ İnhibitör Etkisi
}

\author{
(1) Isnaeni ISNAENI 1*, (1) Esti HENDRADI2, (1) Natalia Zara ZETTIRA2 \\ 1Airlangga University, Faculty of Pharmacy, Department of Pharmaceutical Chemistry, Surabaya, Indonesia \\ 2Airlangga University, Faculty of Pharmacy, Department of Pharmaceutics, Surabaya, Indonesia
}

\begin{abstract}
Objectives: Roselle (Hibiscus sabdariffa L.) is a medicinal plant commonly used as a beverage and herbal medicine. Complex compounds in the aqueous extracts have provided good antibacterial activity by which the growth of gram-negative and -positive bacteria is inhibited. The aims of this research were to formulate hydroxypropyl methylcellulose (HPMC) 6000 gel containing the extract and investigate the inhibitory activity of the extract and its gel formula against Staphylococcus aureus ATCC 25923.

Materials and Methods: Thin layer chromatography (TLC) on silica gel GF254 was used for analyzing flavonoids and polyphenols using butanol: acetic acid: water (4:1:5) and chloroforms: ethyl acetate: formic acid (0.5:9:0.5) as eluent, respectively. A serial dilution of aqueous extract powder in citrate buffer was made to obtain $0.50,0.25,0.10,0.05$, and $0.02 \mathrm{mg} / \mathrm{mL}$ solution. The roselle aqueous extract ( $3 \%$ ) was formulated as a component of gel containing HPMC 6000 in various concentrations (2\%,3\%, and $4 \%$ ). A diffusion agar method on two layers of nutrient agar media was applied using Staphylococcus aureus ATCC 25923 and gentamicin 25 ppm as bacterial test and standard, respectively. After incubation for $24 \mathrm{~h}$ at $37^{\circ} \mathrm{C}$, the inhibitory effect was denoted by a clear zone around the hole and the inhibitory activity was measured as minimum inhibitory concentration (MIC). Results: The aqueous extract of Hibiscus sabdariffa L. contained flavonoid and polyphenol compounds based on the TLC chromatogram profile. It was found that the gel formula containing 3\% HPMC 6000 and 3\% aqueous extract gave a good physical characteristic and the lowest MIC (6.0 mg/ $\mathrm{mL}$ ), equivalent to $7.58 \mathrm{ppm}$ of gentamicin standard at $12.0 \mathrm{mg} / \mathrm{mL}$ concentration.

Conclusion: The HPMC 6000 at 3\% (w/w) concentration in roselle aqueous extract gel preparation gave good physical characteristics. The gel preparation exhibited inhibitory activity against Staphylococcus aureus ATCC 25923 shown by MIC $6.0 \mathrm{mg} / \mathrm{mL}$. Formula 2 is recommended and should be further investigated for implementation in topical preparations.
\end{abstract}

Key words: Inhibitory effect, Hibiscus sabdariffa, HPMC 6000, Staphylococcus aureus

öz

Amaç: Hibiscus sabdariffa L. yaygın olarak içecek ve bitkisel ilaç olarak kullanılan tıbbi bir bitkidir. Sulu ekstrelerindeki kompleks bileşikler, gram negatif ve pozitif bakterilerin büyümesini inhibe ederek antibakteriyel aktivite göstermiştir. Bu araştırmanın amacı, ekstre içeren hidroksipropil metilselüloz (HPMC) 6000 jelini formüle etmek, ekstrenin inhibe edici etkisini ve jel formülünün Staphylococcus aureus ATCC 25923'e karşı gösterdiği inhibitör etkiyi araștırmaktır.

Gereç ve Yöntemler: Elüent olarak butanol: asetik asit: su (4:1:5) ve kloroform:etil asetat: formik asit (0,5:9:0,5) kullanılarak sırasıyla flavonoidleri ve polifenolleri analiz etmek amacıyla silika jel GF254 üzerinde ince tabaka kromatografisi gerçekleştirildi. 0,50, 0,25, 0,10, 0,05 ve 0,02 mg/mL

*Correspondence: E-mail: isna.yudi@gmail.com, Phone: +6281331021303 ORCID-ID: orcid.org/0000-0003-4502-2433

Received: 26.05.2018, Accepted: 24.01.2019

๑Turk J Pharm Sci, Published by Galenos Publishing House. 
konsantrasyonda çözelti elde etmek için sitrat tamponu içinde sulu ekstrenin seri seyreltilmesi yapıldı. Hibiscus sabdariffa'nın sulu ekstresinin (\%3), çeșitli konsantrasyonlarda (\%2, \%3 ve \%4) HPMC 6000 içeren jelleri formüle edildi. Bakteriyel test ve standart olarak sırasıyla Staphylococcus aureus ATCC 25923 ve gentamisin 25 ppm kullanılarak agar ortamına difüzyon agar yöntemi uygulandı. $37^{\circ} C^{\prime}$ de 24 saat inkübasyondan sonra, inhibitör aktivite, minimum inhibitör konsantrasyon (MIC) olarak ölçüldü.

Bulgular: Hibiscus sabdariffa L.'nin sulu ekstresinin, flavonoid ve polifenol bileşikleri içerdiği ince tabaka kromatografisi-kromatogramı ile belirlendi. \%3 HPMC 6000 ve \%3 sulu ekstre içeren jel formülünün, $12,0 \mathrm{mg} / \mathrm{mL}$ konsantrasyonda 7,58 ppm gentamisin standardına eşdeğer olacak şekilde en düşük MIC değerine $(6,0 \mathrm{mg} / \mathrm{mL})$ sahip olduğu ve fiziksel özelliklerinin iyi olduğu bulunmuştur.

Sonuç: Hibiscus sabdariffa sulu ekstresinin \%3 (a/a) konsantrasyonda HPMC 6000 içeren jel formülasyonunda iyi fiziksel özellikler gösterdiği tespit edildi. Jel formülü, Staphylococcus aureus ATCC 25923'e karşı MIC 6,0 mg/mL değeri ile inhibitör aktivite gösterdi. En iyi formül olarak belirlenen formül 2'nin topikal preparatlarda kullanılabilmesi için ileri araştırmalara ihtiyaç vardır.

Anahtar kelimeler: İnhibitör etki, Hibiscus sabdariffa, HPMC 6000, Staphylococcus aureus

\section{INTRODUCTION}

Roselle (Hibiscus sabdariffa L.) is a medicinal plant commonly produced as a beverage and herbal medicine. It has multiple activities, one of which is antibacterial activity. The aqueous extracts of roselle calyces contain saponins, alkaloids, tannins, polyphenols, flavonoids, and their glycosides. The saponins and flavonoids make up the largest content. ${ }^{2,3}$ These compounds indicate synergistic effects. Complex compounds in the extracts have provided good antibacterial activity. ${ }^{4}$ Proto-catechuic acid is a polyphenolic compound found in roselle calyces. It inhibited the bacterial growth of methicillin resistant Staphylococcus aureus, Klebsiella pneumoniae, Pseudomonas aeruginosa, and Acinetobacter baumannii at $5 \mathrm{mg} / \mathrm{mL} .^{5-7}$

In terms of antimicrobial activity, roselle aqueous extract was used at a concentration above its minimum inhibitory concentration (MIC) $3 \%$. The low $\mathrm{pH}$ values of roselle aqueous extract $(2.42 \pm 0.01)$ led to hydroxypropyl methylcellulose (HPMC) 6000 being chosen as a gelling agent at concentrations of $2 \%, 3 \%$, and $4 \%$, because this matrix is stable and indicates good swelling ability in acidic conditions. An effort to discover a new topical dosage form containing roselle extract as active ingredient against infectious diseases was the main target of the present research.

\section{MATERIALS AND METHODS}

\section{Chemicals}

The materials were pharmaceutical grade. Dried aqueous extract of roselle was purchased from PT ASIMAS; HPMC 6000, citric acid monohydrate, sodium citrate dihydrate, propylene glycol, sodium benzoate, gentamicin sulfate, and nutrient agar from Oxoid; sodium chloride from Merck; and distilled water from PD Surabaya Air Suling. Staphylococcus aureus ATCC 25923 was obtained from the Department of Microbiology, Faculty of Medicine, Airlangga University.

\section{Qualitative analysis of roselle aqueous extracts}

Analysis of the extract included an organoleptic examination (shape, odor, and color) and $\mathrm{pH}$, while the chromatogram pattern of flavonoids and polyphenols was analyzed by thin layer chromatography (TLC) on Kiesel Gel $\mathrm{GF}_{254}$ plates. The chromatographic profile of the flavonoids was evaluated by shaking $1 \mathrm{~g}$ of the extract with $n$-hexane repeatedly until it was colorless and the residue was dissolved in $5 \mathrm{~mL}$ of ethanol. Then the solution was spotted and developed in butanol: acetic acid: water $(4: 1: 5, \mathrm{v} / \mathrm{v})$. The presence of flavonoids was denoted by intensive yellow spots on the plate after contact with ammonia fumes. The polyphenols' chromatogram pattern of the extracts was obtained by mixing $1 \mathrm{~g}$ of extract and $10 \mathrm{~mL}$ of hot distilled water at room temperature. The solution was spotted on a TLC plate after filtering and developed in chloroforms:ethyl acetate: formic acid $(0.5: 9: 0.5, \mathrm{v} / \mathrm{v})$ and sprayed with $\mathrm{FeCl}_{3}$ solution for indicating the presence of polyphenols by the appearance of black spots.1.2

\section{Qualitative analysis of HPMC 6000}

The qualitative examination of HPMC 6000 including $\mathrm{pH}$ value and viscosity was analyzed using a $\mathrm{pH}$-meter and Brookfield viscometer, respectively. ${ }^{6,8}$

Viscosity was measured according to the Brookfield viscometer manual. The spindle was lowered and centered in the test material ( $600 \mathrm{~mL}$ in beaker) to meet the "meniscus" of the fluid at the center position of the immersion groove. The viscosity measurement was performed by turning of the switch "ON". Time was allowed for the indicated reading to stabilize. The reading was noted and multiplied by the factor appropriate to the viscometer model/spindle/speed combination being used. The available table or the FACTOR FINDER was referred to for calculating viscosity. Readings below $10.0 \%$ torque (dial reading) should be avoided.

\section{Determining the MIC of roselle aqueous extracts}

The MIC of roselle aqueous extracts was determined by agar diffusion method and molding hole against Staphylococcus aureus ATCC 25923. The bacterial test was cultured on nutrient agar medium slants in glass tubes and incubated for $24 \mathrm{~h}$ at $37^{\circ} \mathrm{C}$. The inoculum suspension was prepared by adding sterile $0.9 \% \mathrm{NaCl}$ solution to fresh culture, shaking, and measuring the optical density at $580 \mathrm{~nm}$ adjusted until $25 \%$ transmittance of inoculum was obtained. The extracts weighed $100 \mathrm{mg}$ and were dissolved in citrate buffer until $10 \mathrm{~mL}$. The solution was diluted to $0.50,0.25,0.10,0.05$, and $0.02 \mathrm{mg} / \mathrm{mL}$ to obtain a concentration higher than the MIC. Two layers of test media were prepared and applied. The agar was perforated with 6 sterile holders. Samples and a positive control (gentamicin 25 $\mathrm{ppm}$ ) were put into each of the holes, incubated at $37^{\circ} \mathrm{C}$ for $24 \mathrm{~h}$, and observed. The growth inhibitory zone diameter was measured and the smallest concentration that still inhibited the growth of the test bacterium (MIC) was determined. 


\section{Formulation of roselle aqueous extracts gel}

Based on the MIC of the roselle extract, the gel formula was examined using the extract at higher concentration than the MIC. Some $7.5 \mathrm{~g}$ of the extracts and $250 \mathrm{mg}$ of sodium benzoate were dissolved in warmed citrate buffer $\left(70-80^{\circ} \mathrm{C}\right)$ and then poured into HPMC 6000 dispersion with $10 \mathrm{~g}$ of propylene glycol. The solution was stirred until gel mass formed and stopped at $35^{\circ} \mathrm{C}$. The composition of the gel formulation is shown in Table 1.

Physical examination of the gel preparation

Physical examination of the gel preparation included viscosity, $\mathrm{pH}$, and dispersive analysis. The analysis of the dispersive power was carried out using two calibration slides. Approximately $1 \mathrm{~g}$ of gel was put in the middle of the slide and covered with the other slide. Weights were orderly added starting from $5 \mathrm{~g}$ on the upper slide. The weight was continuously added until the preparation no longer spread (approximately $5 \mathrm{~min}$ ) and the diameter was recorded. Afterwards, a curve of the relationship between the dispersion diameter $(\mathrm{cm})$ and the weight $(\mathrm{g})$ was observed. The dispersion ability was determined from the slope of the regression equation of the dispersion diameter and the weight. ${ }^{9-11}$ The experiment was replicated three times.

\section{Determining the MIC of the selected formula}

Gel solution of $12.0 \mathrm{mg} / \mathrm{mL}$ was diluted to obtain solution at 6.0 , $3.0,1.5,0.8,0.4,0.2,0.1$, and $0.05 \mathrm{mg} / \mathrm{mL}$ concentrations. The determination of MIC was carried out the same as for the extract. The agar was perforated with 19 sterile holders. Approximately $50 \mu \mathrm{L}$ of the positive control (gentamicin), negative control (gel base), and sample were put into each hole. The disk was incubated at $37^{\circ} \mathrm{C}$ for $24 \mathrm{~h}$ and the growth inhibitory zone and its diameter $(\mathrm{mm})$ were observed and measured. Gentamicin solution at $100 \mathrm{ppm}$ was made and diluted to obtain solution at $25,20,15,10$, and 5 ppm concentrations. A logarithmic test of gentamicin concentration vs. the inhibitory zone diameter $(\mathrm{mm})$ curve was performed and the regression equation obtained was used to calculate the inhibitory activity of the sample solution equally to the gentamicin standard by plotting inhibitory diameter.

\section{Statistical analysis}

The significant difference of inhibitory activity among roselle aqueous extract formulas was determined by one-way variance analysis (ANOVA). Furthermore, the significant differences

\section{Table 1. Gel formula of roselle aqueous extracts}

\begin{tabular}{lllllll} 
Materials & \multicolumn{7}{l}{ Formula } \\
\cline { 2 - 7 } & \multicolumn{7}{l}{ Preparation (\%) } & \multicolumn{3}{l}{ Base (\%) } \\
\cline { 2 - 8 } & 1 & 2 & 3 & 1 & 2 & 3 \\
\hline HPMC 6000 & 2 & 3 & 4 & 2 & 3 & 4 \\
\hline Roselle aqueous extracts & 3 & 3 & 3 & - & - & - \\
\hline Propylene glycol & 5 & 5 & 5 & 5 & 5 & 5 \\
\hline Sodium benzoate & 0.1 & 0.1 & 0.1 & 0.1 & 0.1 & 0.1 \\
\hline Citrate buffer (pH 4.505) & 89.9 & 88.9 & 87.9 & 92.9 & 91.9 & 90.9 \\
\hline HPMC: Hydroxypropyl methylcellulose & & & & &
\end{tabular}

were determined by the honestly significant difference test with the reliability value of $0.95(\alpha=0.05)$. If the value is $>0.05$ then there is no significant difference between the tested formulas.

This study does not require ethics committee approval or patient informed consent.

\section{RESULTS}

Screening of the extract contents was carried out according to Marliana et al. ${ }^{12}$ and Villani et al. ${ }^{13}$ Based on the profile of the TLC chromatogram, roselle aqueous extracts contained polyphenols and flavonoids as reported in previous research. ${ }^{14}$ The $\mathrm{pH}$ value of the extract was $2.54 \pm 0.004$, close to the literature $(2.42 \pm 0.01)^{2,3}$

Regardless of HPMC qualification, its viscosity was $>100$ cPss at $2 \%$ concentration. ${ }^{15,16}$ The viscosity criterion was accepted if the measured result was not less than $75.0 \%$ and not more than $140.0 \%$.

The MIC of the roselle aqueous extracts was $0.1 \mathrm{mg} / \mathrm{mL}$ against Staphylococcus aureus ATCC 25923 (Table 2, Figures 1 and 2). This value is higher than that in previous research; the MIC of the aqueous extracts of roselle calyces against Staphylococcus aureus and Streptococcus faecalis was reported as $0.5 \mathrm{mg} /$ $\mathrm{mL}$. Furthermore, Escherichia coli, Klebsiella pneumoniae, and Salmonella typhi were inhibited by the MIC value of $1.0 \mathrm{mg} / \mathrm{mL}^{7.16}$ Despite these effects, roselle extracts have a therapeutic effect for gastrointestinal infection, diarrhea, and skin diseases. ${ }^{7}$

The viscosity and $\mathrm{pH}$ values of the gel base and its preparation are depicted in Figures 3 and 4 . It was found that viscosity of

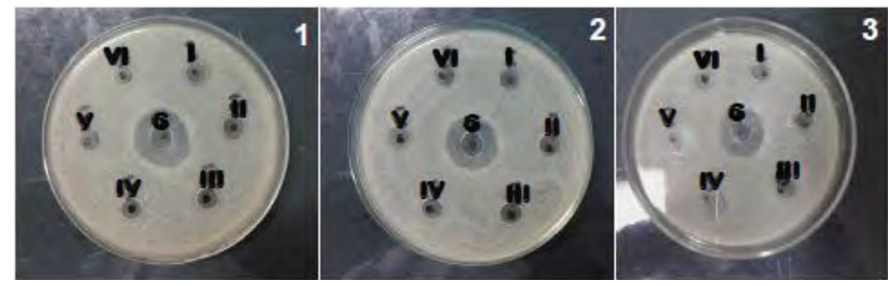

Figure 1. The result of MIC determination of roselle aqueous extracts (1, 2 , 3=triple replication; I=0.50 mg/mL; $\|=0.25 \mathrm{mg} / \mathrm{mL} ;\| I=0.12 \mathrm{mg} / \mathrm{mL} ; \mid \mathrm{V}=0.10$ $\mathrm{mg} / \mathrm{mL} ; \mathrm{V}=0.05 \mathrm{mg} / \mathrm{mL} ; \mathrm{Vl}=0.02 \mathrm{mg} / \mathrm{mL} ; \mathrm{G}=$ gentamicin $25 \mathrm{ppm}$ )

MIC: Minimum inhibitory concentration

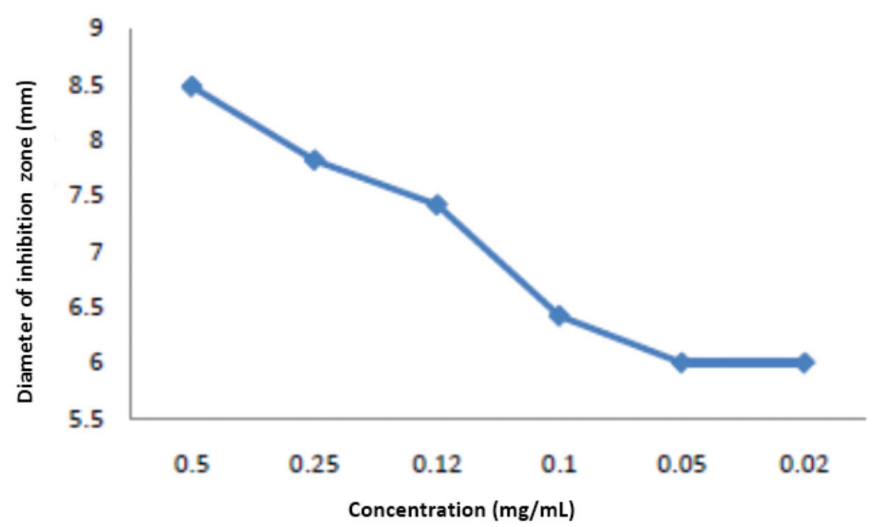

Figure 2. Graph of inhibitory activity of roselle aqueous extracts 
the gel preparation containing aqueous roselle extracts was higher than that of the gel base (without the roselle extract). On the other hand, the $\mathrm{pH}$ value of the gel preparation was lower than that of the gel base.

The dispersive power analysis of the gel base and gel preparation depicted in Figure 5 showed that both the gel base and preparations of $1^{\text {st }}$ and $2^{\text {nd }}$ formulas reached the maximum dispersion capacity at $10 \mathrm{~g}$ and $35 \mathrm{~g}$ loading load (the weight of the load placed on the gel base and gel preparation), respectively, while the $3^{\text {rd }}$ formula reached maximum dispersion capacity at 65 g loading load.

The bacterial inhibitory activity of the gel preparations indicated that the greater concentration of HPMC, the lower inhibition

\section{Table 2. The result of MIC determination of roselle aqueous extracts}

\begin{tabular}{lllll} 
Rep Conc. (mg/mL) & \multicolumn{5}{c}{ Inhibitory diameter $(\mathrm{mm})$} \\
\cline { 2 - 5 } & 1 & 2 & 3 & Average \\
\hline 0.50 & 8.80 & 8.65 & 8.00 & $8.48 \pm 0.42$ \\
\hline 0.25 & 8.20 & 7.70 & 7.55 & $7.82 \pm 0.34$ \\
\hline 0.12 & 7.70 & 7.35 & 7.20 & $7.42 \pm 0.26$ \\
\hline 0.10 & 6.65 & - & 6.60 & $6.62 \pm 0.05$ \\
\hline
\end{tabular}

\begin{tabular}{lllll}
\hline 0.05 & - & - & - & - \\
\hline
\end{tabular}

0.02

Diameter of reservoir: $6.00 \mathrm{~mm}$, MIC: Minimum inhibitory concentration

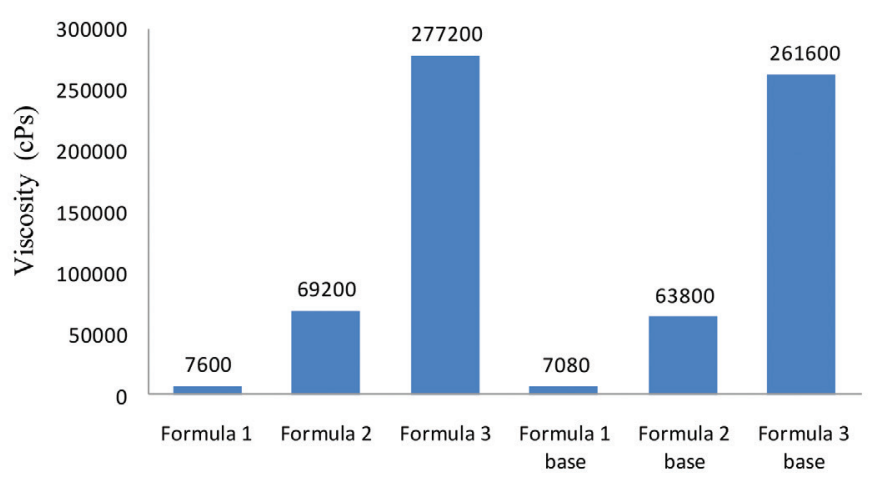

Figure 3. Graph of the viscosity of the gel preparation of roselle aqueous extracts and gel/formula base

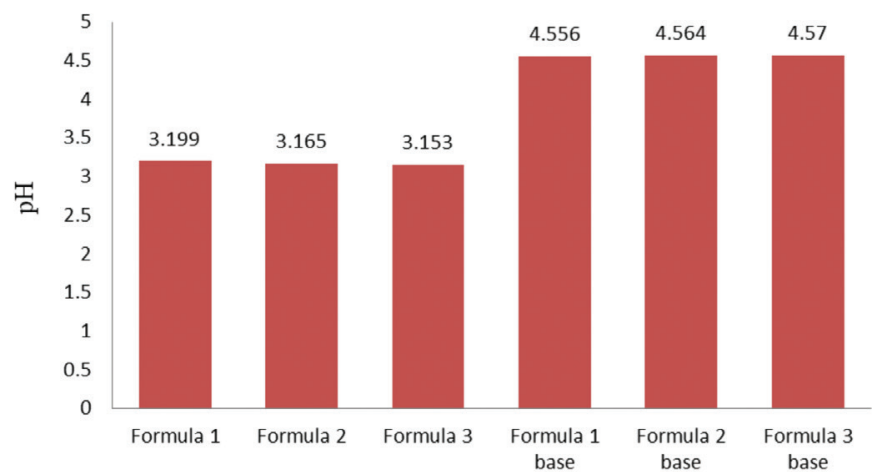

Figure 4. Graph of the $\mathrm{pH}$ of the gel preparation and gel/formula base of roselle aqueous extracts activity was obtained (Figure 6 and Table 3). The greater the viscosity of the gel preparation, the lower capacity of active material to be released. ${ }^{9-11}$

Based on the physical evaluation, formula 2 was chosen, because its viscosity was close to the specification $(30.000$ cPs). The result of the MIC determination of formula 2 (Figure 7 ), the inhibitory diameter (Table 4), and the inhibitory graph of formula 2 (Figure 8 ) were analyzed statistically. Gentamicin 25 ppm was chosen as the positive control to ensure that the bacterial test used in this research was sensitive against the antibiotic. A serial concentration of gentamicin was used as the standard curve for evaluation of the extract potency relative to the standard.

Based on one-way ANOVA, there was a significant difference between the inhibitory activity of 12.0 and $6.0 \mathrm{mg} / \mathrm{mL}$, and there was no significant difference between $3.0,1.5$, and $0.8 \mathrm{mg} / \mathrm{mL}$ of the gel preparation. In conclusion, formula 2 exhibited MIC at $6.0 \mathrm{mg} / \mathrm{mL}$ against Staphylococcus aureus ATCC 25923.

The inhibitory activity of gentamicin at serial dilution against the test bacterium was evaluated by a regression equation, where $Y$ and $X$ were the diameter of the inhibitory zone $(\mathrm{mm})$ and $\mathrm{log}$ of concentrations (ppm), respectively. The log concentration of formula 2 with diameter of inhibitory zone $9.75 \mathrm{~mm}$ was calculated by the regression equation. Equivalent to this growth inhibitory diameter (x), 7.58 ppm of gentamicin concentration was obtained. Furthermore, the inhibitory potency of the roselle aqueous extracts gel at $12.0 \mathrm{mg} / \mathrm{mL}$ (roselle concentration in gel 3\% w/w) against Staphylococcus aureus ATCC 25923 was equal to $7.58 \mathrm{ppm}$ of the gentamicin sulfate standard solution.

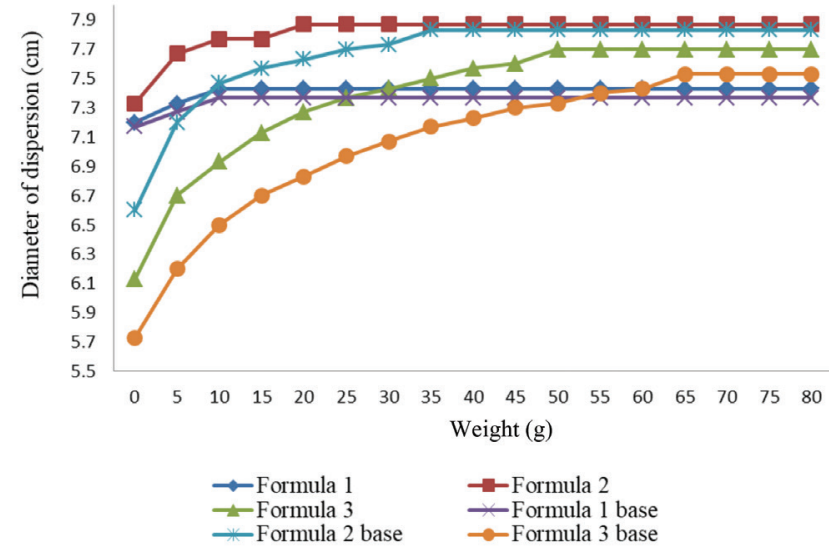

Figure 5. Graph of dispersive power of the gel preparation and gel/formula base of roselle aqueous extracts

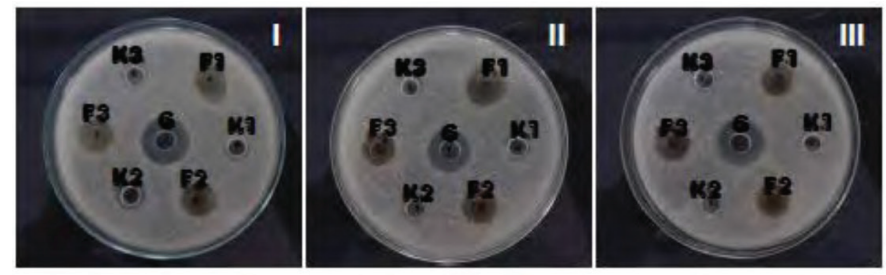

Figure 6. The antibacterial activities of formula 1,2 and 3 at $12.0 \mathrm{mg} / \mathrm{mL}(\mathrm{I}$, $\mathrm{II}$, and III=replication; $F 1=$ formula $1 ; F 2=$ formula $2 ; F 3=$ formula $3 ; \mathrm{K} 1=$ formula base 1; $K 2$ =formula base 2; $K 3$ =formula base 3; $G$ =gentamicin 25 ppm) 


\section{DISCUSSION}

Identification of polyphenols and flavonoids in the chromatogram pattern showed that they play an important role in antibacterial activity. $4,12,14$ The $\mathrm{pH}$ of $1 \%$ solution of roselle aqueous extracts was highly acidic due to high organic acid contents, such as malic acid and ascorbic acid. The acidity of roselle also plays an important role in its antibacterial activity. 1,2,14 The qualification of the HPMC 6000 indicated that the matrix had viscosity

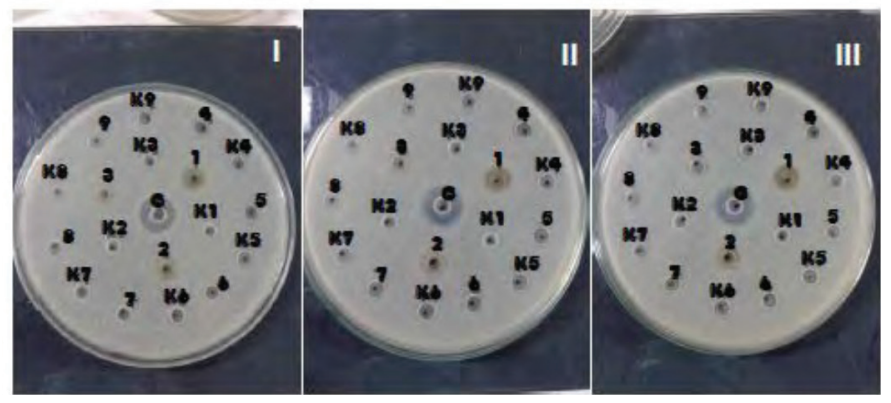

Figure 7. The result of the MIC determination of formula 2 (I, II, III=replication 3; $1=12.0 \mathrm{mg} / \mathrm{mL} ; 2=6.0 \mathrm{mg} / \mathrm{mL} ; 3=3.0 \mathrm{mg} / \mathrm{mL} ; 4=1.5 \mathrm{mg} / \mathrm{mL} ; 5=0.8 \mathrm{mg} / \mathrm{mL}$; $6=0.4 \mathrm{mg} / \mathrm{mL} ; 7=0.2 \mathrm{mg} / \mathrm{mL} ; 8=0.1 \mathrm{mg} / \mathrm{mL} ; 9=0.05 \mathrm{mg} / \mathrm{mL} ; \mathrm{K} 1=$ dilution base $1 ;$ $\mathrm{K} 2=$ dilution base 2 ; $\mathrm{K} 3=$ dilution base 3 ; $\mathrm{K} 4=$ dilution base 4 ; $\mathrm{K} 5=$ dilution base 5; $\mathrm{K} 6=$ dilution base $6 ; \mathrm{K} 7=$ dilution base 7 ; $\mathrm{K} 8=$ dilution base 8 ; $\mathrm{K} 9=$ dilution base 9; $\mathrm{G}=$ gentamicin at $25 \mathrm{ppm}$ ), MIC: Minimum inhibitory concentration satisfactory for a gelling agent. The $\mathrm{pH}$ value of $2 \% \mathrm{w} / \mathrm{w}$ solution of HPMC 6000 in water was $4.445 \pm 0.053$ stabilized by the acidic properties of the extract. The $\mathrm{pH}$ value was different from the literature (5.0-8.0) $)^{15}$ possibly because of the different producers, the quality, and the storage condition of the raw materials.

It was found that the MIC of the roselle aqueous extracts against Staphylococcus aureus ATCC 25923 was $0.1 \mathrm{mg} / \mathrm{mL}$. This value was used as the concentration of the formula, to which $3 \% \mathrm{w} / \mathrm{w}$

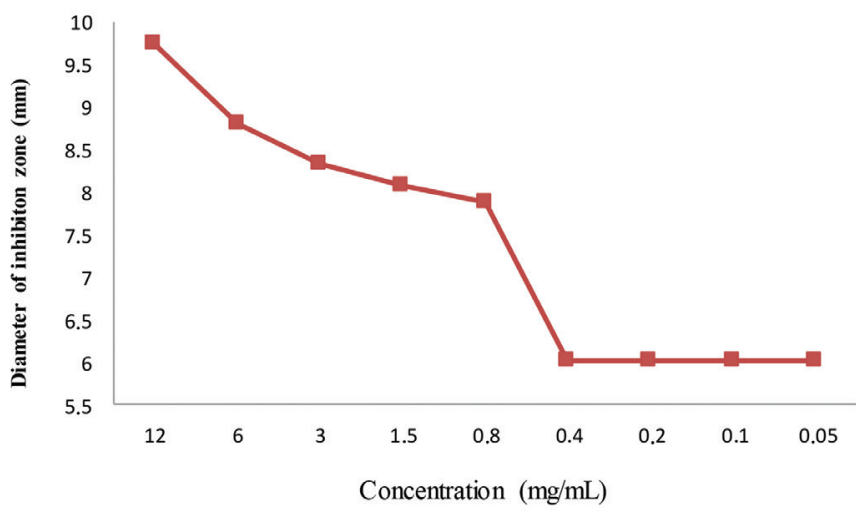

Figure 8 . Inhibitory activity of the formula 2 gel preparation of roselle aqueous extracts

Table 3. Inhibitory diameter of formulas 1, 2, and 3 gel preparation of roselle aqueous extracts

\begin{tabular}{|c|c|c|c|c|c|c|}
\hline \multirow{3}{*}{ Replication } & \multicolumn{6}{|c|}{ Inhibitory diameter (mm) } \\
\hline & \multicolumn{3}{|l|}{ Formula } & \multicolumn{3}{|c|}{ Formula base } \\
\hline & 1 & 2 & 3 & 1 & 2 & 3 \\
\hline 1 & 10.70 & 10.10 & 9.45 & 7.30 & 7.05 & 6.80 \\
\hline 2 & 11.00 & 9.80 & 9.70 & 6.70 & 6.20 & 6.05 \\
\hline 3 & 10.70 & 9.50 & 9.00 & 6.50 & 6.05 & 6.10 \\
\hline Average & $10.80 \pm 0.17$ & $9.80 \pm 0.30$ & $9.38 \pm 0.36$ & $6.83 \pm 0.42$ & $6.43 \pm 0.54$ & $6.32 \pm 0.42$ \\
\hline
\end{tabular}

Diameter of reservoir: $6.00 \mathrm{~mm}$

Table 4. The result of the MIC determination of formula 2 gel preparation of roselle aqueous extracts

\begin{tabular}{|c|c|c|c|c|c|c|c|c|c|}
\hline \multirow[t]{3}{*}{ Rep Conc. } & \multirow[t]{3}{*}{$(\mathrm{mg} / \mathrm{mL})$} & \multicolumn{8}{|c|}{ Inhibitory diameter (mm) } \\
\hline & & \multicolumn{4}{|c|}{ Preparation } & \multicolumn{4}{|l|}{ Base } \\
\hline & & 1 & 2 & 3 & Average & 1 & 2 & 3 & Average \\
\hline 6.00 & & 8.60 & 8.70 & 9.10 & $8.80 \pm 0.26$ & 8.40 & - & 8.55 & $8.47 \pm 0.15$ \\
\hline 3.00 & & 8.35 & 8.35 & 8.30 & $8.33 \pm 0.03$ & 8.30 & 8.30 & 8.00 & $8.20 \pm 0.17$ \\
\hline 0.80 & & 8.10 & 8.00 & 7.50 & $7.87 \pm 0.32$ & 8.00 & 8.00 & 7.30 & $7.77 \pm 0.40$ \\
\hline 0.40 & & - & - & - & - & - & - & - & - \\
\hline 0.20 & & - & - & - & - & - & - & - & - \\
\hline
\end{tabular}


was set as the extract concentration based on the preliminary optimization.

The gel formula was tested using three concentrations of HPMC 6000 (2\%, 3\%, and 4\%,w/w). The ingredients of the preparation formula were propylene glycol as a humectant, roselle aqueous extracts as an active material, sodium benzoate as a preservative, and citrate acid and sodium citrate as buffer. The gel base preparation without the extracts was formulated to identify the effect of roselle aqueous extracts on the physical characteristics of the gel preparation. The gel preparation was made of $250 \mathrm{~g}$ with citrate buffer dissolved with $\mathrm{pH}$ of 4.505 and each formula was made for one dosage. Replication was not performed due to the limited number of roselle aqueous extracts. It was found that the viscosity of formulas 1, 2, and 3 was $7600,69.200$ and 277.200 cPs, respectively. On the other hand, the viscosity of the gel base of formulas 1, 2, and 3 was $7080,63.800$ and $261.600 \mathrm{cPs}$, respectively. The presence of roselle aqueous extracts $3 \% \mathrm{w} / \mathrm{w}$ increased the viscosity.

The $\mathrm{pH}$ value of formulas 1,2 , and 3 was $3.199 \pm 0.003$, $3.165 \pm 0.002$, and $3.153 \pm 0.006$, respectively. The $\mathrm{pH}$ value of the base gel formulas 1,2 , and 3 was $4.556 \pm 0.006,4.564 \pm 0.006$, and $4.570 \pm 0.006$, respectively. It can be concluded that the $\mathrm{pH}$ of the preparation was much lower than the $\mathrm{pH}$ of the gel base even though they were treated by citrate with 0.02 of buffer capacity. This occurred because the buffer capacity failed to hold the $\mathrm{pH}$ of the preparation containing $3 \%(\mathrm{w} / \mathrm{w})$ quite acidic extract of roselle aqueous extracts. The statistical test using one-way ANOVA ( $p=0.05$ ) showed that there was a significant difference among the $\mathrm{pH}$ of formulas 1,2 , and 3 , as well as the $\mathrm{pH}$ of the gel base formulas 1, 2, and 3 .

The slope calculation of the regression equation of the dispersion diameter vs. weight of loads to evaluate the dispersal ability of the gel preparation and the base gel of formulas 1 , 2 , and 3 as depicted in Figure 5 was performed statistically by one-way ANOVA ( $p=0.05)$. It was found that there was no significant difference in the slope between formulas 1 and 2 , but a significant difference was found between formulas 1 and 3 and between formulas 2 and 3 . The significant difference in the slope no found between formula 1 and formula gel base; formula 2 and gel base 2; but no significant difference between formula 3 and gel base 3 . The capacity of dispersion was denoted by the diameter of maximum dispersion on the adding of certain loads, by which the gel preparation was not dispersed anymore.

According to the slope value and the loads to reach maximum dispersion capacity, it can be concluded that the gel preparation formula dispersed more easily than the gel base, because the viscosity of the gel base is lower than that of the preparation. Since the $\mathrm{pH}$ value of the gel preparation was close to 3 and the analysis of the dispersive power was conducted 30 days after the preparation was made, this might have caused the gel preparation to become unstable. The viscosity of the HPMC solution was stable at $\mathrm{pH} 3-11$, but the stability might be disturbed if there is an active material that possesses strong acidity. ${ }^{15}$ In the present research, the active material was acid solution of the roselle aqueous extracts.
The inhibitory activity test of the gel base was performed to minimize the effects of the gel component. The activity test aimed to ensure that the growth inhibitory responses were derived from the gel preparation. The bioassay indicated that the gel preparation exhibited higher inhibitory activity than the gel base. The gel preparation of formulas 1, 2, and 3 exhibited growth inhibitory diameter of $10.80 \pm 0.17 \mathrm{~mm}, 9.80 \pm 0.30 \mathrm{~mm}$, and $9.38 \pm 0.36 \mathrm{~mm}$, respectively. The one-way ANOVA ( $p=0.05)$ showed that there was a significant difference between formulas 1 and 2, as well as between formulas 1 and 3 . There was no significant difference between formulas 2 and 3 . The viscosity of the gel preparation might affect the release of the active materials. The higher the viscosity, the more difficult the active materials are released, because of the difficult mobility of the active materials. ${ }^{9-11}$

Based on the physical characterization, the selected gel preparation was formula 2, the one containing HPMC 6000 concentration of $3 \%(\mathrm{w} / \mathrm{w})$ with specification of acid gel preparation with viscosity of 30.000 cPs. The three formulas had $\mathrm{pH}$ values that did not meet the specification. Therefore, the formula was selected in accordance with the viscosity value that was close to the specification, namely formula 2 . Then the MIC of formula 2 was determined. The preparation was diluted until it reached a concentration of $0.05 \mathrm{mg} / \mathrm{mL}$. The growth inhibitory activity appeared at a dilution of $12.0-0.8 \mathrm{mg} /$ $\mathrm{mL}$. However, the zone was higher than that of the gel base. The statistical test using one-way ANOVA indicated that there was a significant difference between the activity of the gel preparation at 12.0 and $6.0 \mathrm{mg} / \mathrm{mL}$ and the gel base. In addition, a significant difference was not found between the inhibitory activity of the gel preparation with concentration of 3.0, 1.5, and $0.8 \mathrm{mg} / \mathrm{mL}$ and the gel base. The nonsignificant difference between the gel preparation and the gel base indicated that the inhibitory activity was not caused by the roselle aqueous extracts, but was affected by other components in the formula, such as propylene glycol and sodium benzoate. The smallest concentration showed the existence of a significant difference between the inhibitory activity of the preparation and the gel base at $6.0 \mathrm{mg} / \mathrm{mL}$. In conclusion, the concentration of the roselle aqueous extracts of formula 2 might be recommended for its antibacterial activity toward Staphylococcus aureus ATCC 25923. The MIC of the gel preparation was higher than that of the roselle aqueous extracts, because the gelling agent/polymer of the gel preparation might have affected the release of the roselle aqueous extracts from the three preparation formulas.

The potential ratio of formula 2 that inhibited the test bacterium was determined using gentamicin sulfate standard. Correlation between the growth inhibitory diameter of the gentamicin solution at 5-25 ppm against Staphylococcus aureus ATCC 25923 and the concentration log of the gentamicin standard was used to determine the potency of the gel preparation through the regression equation: $y=10.2584 x+0.5479$ with $r=0.9837$. Formula 2 exhibited growth inhibitory activity against Staphylococcus aureus ATCC 25923 equal to gentamicin sulfate standard solution of $7.58 \mathrm{ppm}$. 


\section{CONCLUSION}

The HPMC 6000 at $3 \%(\mathrm{w} / \mathrm{w})$ concentration in roselle aqueous extracts gel preparation gave good physical characteristics. The gel preparation exhibited inhibitory activity against Staphylococcus aureus ATCC 25923 depicted by MIC $6.0 \mathrm{mg} / \mathrm{mL}$. Formula 2 is recommended and should be further investigated for implementation in topical preparations.

\section{ACKNOWLEDGMENTS}

The authors thank the Faculty of Pharmacy, Airlangga University for supporting facilities and materials.

Conflicts of interest: No conflict of interest was declared by the authors. The authors alone are responsible for the content and writing of the paper.

\section{REFERENCES}

1. Da-Costa-Rocha I, Bonnlaender B, Sievers H, Pischel I, Heinrich M. Hibiscus sabdariffa L. - a phytochemical and pharmacological review. Food Chem. 2014;165:424-443.

2. Jung EK, Kim YJ, Joo N. Physicochemical properties and antimicrobial activity of Roselle (Hibiscus sabdariffa L.). J Sci Food Agric. 2013;93:37693776.

3. Alaga TO, Edema MO, Atayese AO, Bankole MO. Phytochemical and in vitro anti-bacterial properties of Hibiscus sabdariffa $L$ (Roselle) juice. Journal of Medicinal Plant Research. 2014;8:339-344.

4. Borras-Linares I, Fernandez-Arroyo S, Arraez-Roman D, PalmerosSuarez PA, Del Val-Diaz R, Andrade-Gonzales I, Fernandez-Gutierrez A, Gomez-Leyva JF, Segura-Carretero A. Characterization of phenolic compounds, anthocyanidin, antioxidant and antimicrobial activity of 25 varieties of Mexican Roselle (Hibiscus sabdariffa). Ind Crop Prod. 2015;69:385-394.
5. Liu K, Tsao S, Yin M. In vitro antibacterial activity of roselle calyx and protocatechuic acid. Phytother Res. 2005;19:942-945.

6. Navarro VM, Rojas G, Zepeda LG, Aviles M, Fuentes M, Herrera A, Jimenez $E$. Antifungal and antibacterial activity of four selected Mexican medicinal plants. Pharm Biol. 2006;44:297-300.

7. Olaleye MT. Cytotoxicity and antibacterial activity of methanolic extract of Hibiscus sabdariffa. Journal of Medicinal Plants Research. 2007;1:9-13.

8. Brookfield Engineering Laboratories, Inc.11 Commerce Boulevard, Middleboro, MA 02346-1031 USA.

9. Gendy AM, Jun HW, Kassem AA. In vitro release studies of flurbiprofen from different topical formulations. Drug Dev Ind Pharm. 2002;28:823831.

10. Ueda CT, Shah VP, Derdzinski K, Ewing G, Flynn G, Maibach H, Marques M, Rytting H, Shaw S, Thakker K, Yacobi A. Topical and transdermal drug products. Pharmacopeial Forum. 2009;35:750-764.

11. Olejnik A, Goscianska J, Nowak I. Active compounds release from semisolid dosage forms. J Pharm Sci 2012;101:4032-4045.

12. Marliana SD, Suryanti V, Suyono. Skrining fitokimia dan analisis kromatografi lapis tipis komponen kimia buah labu siam (Sechium edule Jacq. Swartz.) dalam ekstrak etanol. Biofarmasi. 2015;3:26-31.

13. Villani T, Juliani HR, Simon JE, Wu QL. Hibiscus sabdariffa: phytochemistry, quality control, and health properties. In: African Natural Plant Products 2013;2:210-215

14. Al-Hashimi AG. Antioxidant and antibacterial activities of Hibiscus sabdariffa L. extracts. Afr J Food Sci. 2012;6:506-511.

15. Rowe RC, Sheskey PJ, Quinn ME. Handbook of Pharmaceutical Excipients (6 $6^{\text {th }}$ ed). Washington: American Pharmacists Association; 2009:326-328.

16. Ford JL. Design and evaluation of hydroxypropyl methyl cellulose matrix tablets for oral controlled release: a historical perspective. In: Timmins P, Pygall S, Melia C, eds. Hydrophilic Matrix Tablets for Oral Controlled Release. New York; Springer; 2014:17-51. 